Ekonomia - Wroclaw Economic Review 23/1 (2017)

Acta Universitatis Wratislaviensis

No 3754

DOI: $10.19195 / 2084-4093.23 .1 .3$

\author{
Mirosława Janoś-Kresło \\ Szkoła Główna Handlowa w Warszawie \\ e-mail: mjanos@sgh.waw.pl
}

\title{
Niedobory konsumpcji \\ w gospodarstwach domowych z dziećmi z niepełnosprawnością
}

\author{
JEL Classification: D12, D14
}

Keywords: Consumption, shortages, households, children with disabilities

\section{Abstract \\ Consumption Deficiency in Households with Children with Disabilities}

Not every household can afford, mainly due to limited financial resources, to meet their needs in a satisfactory manner. The aim of the article is to present selected findings of empirical research (qualitative study - FGI, IDI and quantitative study - CAPI and CAWI, requested by the respondent) carried out for the needs of the project Entrepreneurial and Consumer Behaviour of Families Caring for Children and Youth with Disabilities. The article presents the financial situation of households with a child/children with disabilities, the financial obligations and purposes of consumer credits and loans, the most acute shortages in the household, the allocation of additional income and the ways of coping with difficulties.

\section{Wprowadzenie}

Celem opracowania jest zaprezentowanie wybranych wyników badań empirycznych (jakościowych i ilościowych) przeprowadzonych na potrzeby projektu pt. „Zachowania przedsiębiorcze i konsumpcyjne w rodzinach opiekujących się dziećmi i młodzieżą z niepełnosprawnością", a dotyczących niedoborów konsumpcji w gospodarstwach domowych z dzieckiem/dziećmi z niepełnosprawnością ${ }^{1}$. Pytanie brzmiało: w jakim obszarze potrzeb/towarów i usług gospodarstwo domowe odczuwa największe braki? W badaniu poproszono także respondentów o odpowiedzi na pytania dotyczące sytuacji finansowej gospodarstwa domowego,

1 Projekt został sfinansowany ze środków Narodowego Centrum Nauki przyznanych na podstawie decyzji numer DEC-2013/09/B/HS4/01965, realizowany był w latach 2014-2016 w Zakładzie Badań Zachowań Konsumentów w Instytucie Zarządzania SGH.

Ekonomia - Wroclaw Economic Review 23/1 (2017)

(C) for this edition by CNS 
bo to dochód jest czynnikiem warunkującym poziom zaspokajania potrzeb gospodarstwa i jego członków. Przedmiotem zainteresowania były także cele konsumpcyjne, na jakie została zaciągnięta pożyczka lub kredyt, oraz korzystanie z pomocy/wsparcia innych osób/instytucji. Powyższe rozważania zostały przedstawione na tle znaczenia przypisywanego konsumpcji.

\section{Znaczenie przypisywane konsumpcji}

Konsumpcja to najogólniej mówiąc proces zaspokajania różnorodnych potrzeb, który był, jest i będzie, proces konsumowania jest bowiem procesem ciągłym. Zmianie, na skutek zachodzących procesów gospodarczych, społecznych i kulturowych, ulega jednak struktura i zakres potrzeb, rozszerzają się możliwości ich zaspokajania, czemu sprzyja obfitość dóbr. Zmieniają się także zachowania konsumentów, którzy stają się coraz bardziej aktywnymi uczestnikami rynku.

Na konsumpcję należy więc patrzeć jak na „dynamiczny i wieloetapowy proces, wynikający z rozmaitych potrzeb" (Bylok, 2013, s. 18). Konsumpcja pozwala człowiekowi nie tylko utrzymać się przy życiu, zachować kondycję fizyczną i psychiczną, umożliwia rozwój osobowości, ale także przez konsumpcję jednostki budują swoją tożsamość, realizują potrzebę identyfikacji.

Konsumpcji przypisywane są różne znaczenia. W 2013 roku zdecydow na większość badanych uznała, że konsumpcja głównie zaspokaja potrzeby bez żadnych innych znaczeń. Niewiele mniej wskazań dotyczyło określenia, że konsumpcja głównie dostarcza przyjemności, satysfakcji. Poniżej 50\% odpowiedzi „zdecydowanie bliskie” i „raczej bliskie” uzyskały takie znaczenia przypisywane konsumpcji, jak: konsumpcja służy demonstrowaniu zamożności, konsumpcja służy demonstrowaniu własnej indywidualności oraz służy jako wyznacznik statusu społecznego (rysunek 1).

Co prawda bogactwo i dobrobyt sytuują się na dalszych miejscach w hierarchii najważniejszych wartości w życiu, ale sytuacja materialna nie pozostaje bez wpływu na tę hierarchię. Wzrost zadowolenia $\mathrm{z}$ warunków materialnych gospodarstwa domowego przekłada się na wzrost znaczenia przypisywanego takim wartościom, jak rodzina, przyjaciele oraz wykształcenie i na spadek takich wartości, jak spokój oraz szacunek innych osób (Wartości i normy, 2013). Można powiedzieć, że współczesna konsumpcja jest czymś ważnym nie tylko w wymiarze jednostkowym, lecz także społecznym.

Nie wszystkie gospodarstwa domowe mogą jednak sobie pozwolić na zaspokojenie potrzeb w sposób satysfakcjonujący, odczuwają niedobory konsumpcji. Dlatego też ważnym problemem jest identyfikacja odczuwanych braków w konsumpcji gospodarstw domowych $\mathrm{z}$ dzieckiem/dziećmi z niepełnosprawnością, zwłaszcza tych najpilniejszych, a wiedza ta powinna być przydatna w podejmowaniu działań mających na celu wsparcie tych rodzin. 


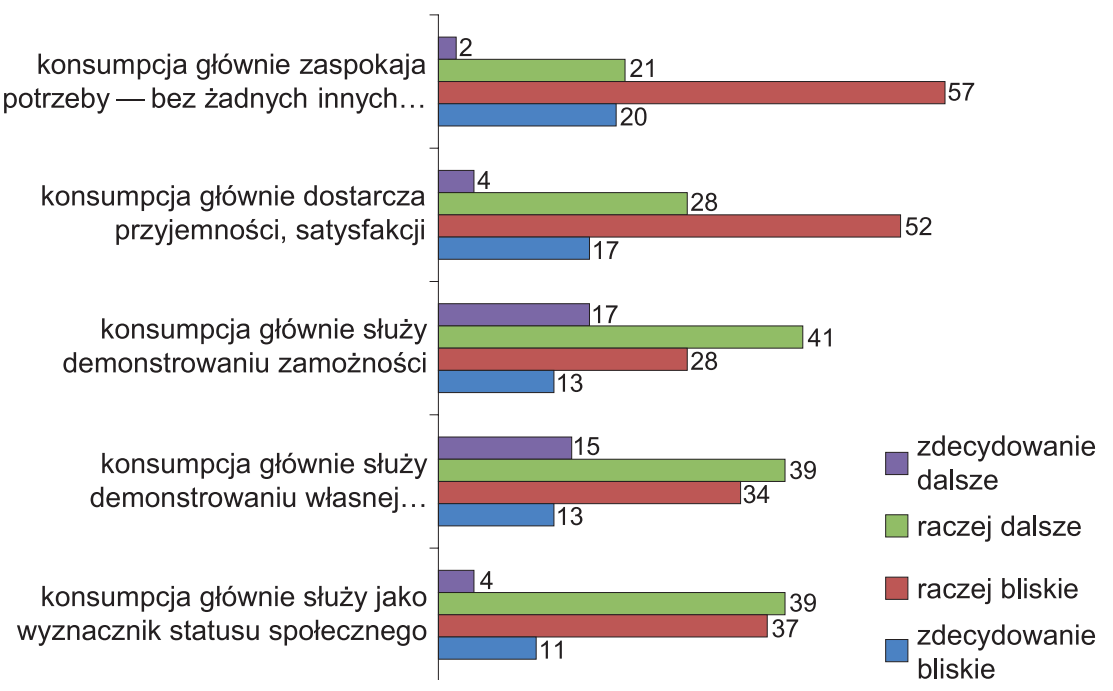

Rysunek 1. Znaczenie przypisywane konsumpcji przez gospodarstwa domowe (\%)

Źródło: Dąbrowska et al., (2013, s. 128).

\section{Metodyka badania}

Na potrzeby realizowanego projektu badawczego pt. „Zachowania przedsiębiorcze i konsumpcyjne w rodzinach opiekujących się dziećmi i młodzieżą z niepełnosprawnością" zostały przeprowadzone badania empiryczne. Badania jakościowe (FGI Focus Group Interview i IDI - Individual in-Depth Interview) zostały przeprowadzone w 2014 r. Badanie ilościowe, w oparciu na autorskim kwestionariuszu ankiety, przeprowadzone zostało w I kwartale 2015 r. na ogólnopolskiej próbie $\mathrm{N}=686$ respondentów, rodziców/opiekunów dzieci z niepełnosprawnością do lat 18. Badanie przeprowadzono metodą CAPI (Computer Assisted Personal Interview), a na wyraźne życzenie respondenta — metodą CAWI (Computer Assisted Web Interview).

\section{Odczuwane braki i sposoby radzenia sobie z trudnościami w gospodarstw domowych z dzieckiem/dziećmi z niepełnosprawnością}

\subsection{Sytuacja dochodowa gospodarstw domowych z dzieckiem/dziećmi z niepełnosprawnością}

Dochody, ich poziom i źródła pozyskiwania są najważniejszym czynnikiem kształtującym poziom i strukturę konsumpcji, głównym wyznacznikiem poziomu zaspokojenia potrzeb w wymiarze zarówno ilościowym, jak i jakościowym. 
Ocena sytuacji finansowej rodzin z dziećmi z niepełnosprawnością w kontekście danych budżetów domowych GUS w latach 2013-2014 wykazała relatywnie wysokie przychody ogółem w ujęciu średnim. Średnia arytmetyczna $(5031,41$ zł/ gospodarstwo w 2013 roku oraz 5001,4 zł w 2014 roku) jest jednak znacznie zawyżona przez silną dodatnią asymetrię rozkładu przychodów. Oznacza to, że w obu latach w ujęciu ogółem (w subgrupie było blisko 600 rodzin) zdecydowanie przeważały gospodarstwa ze stosunkowo niskimi przychodami, ale były gospodarstwa z dziećmi z niepełnosprawnością, które miały bardzo wysokie przychody, aczkolwiek w stosunku do średniej zróżnicowanie nie było w obu latach zbyt wysokie (Janoś-Kresło et al., 2016, s. 95).

W przeprowadzonym badaniu empirycznym wśród 686 takich rodzin 14\% dysponowało miesięcznie dochodem poniżej $1500 \mathrm{z}$ z/gospodarstwo, 55\% miało dochody w przedziale $1501-5000 \mathrm{zł} \mathrm{miesięcznie,} \mathrm{a} \mathrm{14 \%} \mathrm{powyżej} 5001 \mathrm{zł} /$ miesiąc.

Na pytanie o ocenę obecnej sytuacji finansowej rodziny/gospodarstwa domowego zdecydowana większość odpowiedziała, że jest ona przeciętna — starcza na co dzień, ale musimy oszczędzać. Niemniej jednak oceny pozytywne: dobrze środków finansowych starcza na wszystkie potrzeby i bardzo dobrze - możemy sobie pozwolić na pewien luksus i na gromadzenie oszczędności, przeważały nad negatywnymi: bardzo źle — nie wystarcza na podstawowe potrzeby i źle — żyjemy bardzo skromnie, musimy na co dzień bardzo oszczędzać (rysunek 2).

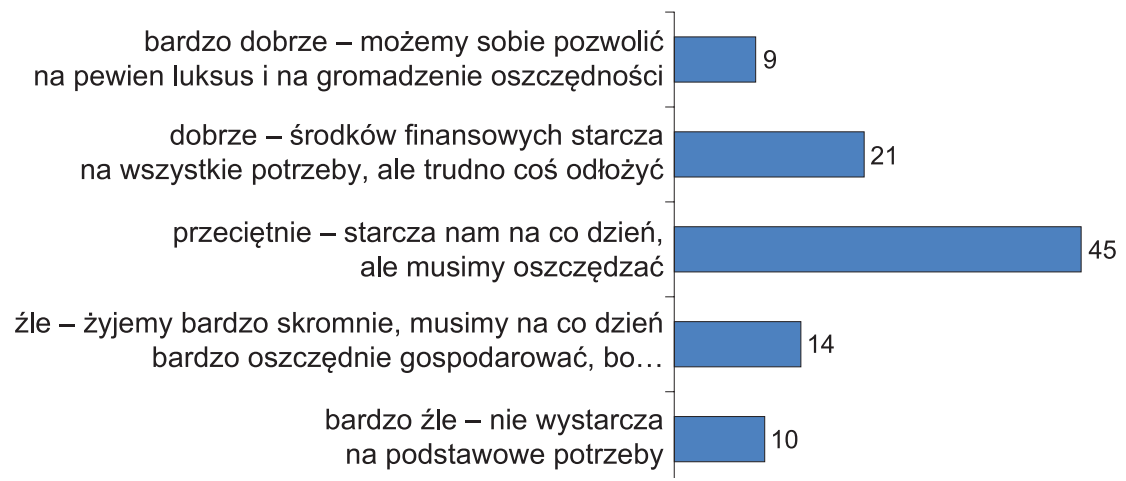

Rysunek 2. Samoocena sytuacji finansowej rodziny/gospodarstwa domowego (\%)

Źródło: badanie własne, 2015.

Ocena sytuacji finansowej jest zróżnicowana ze względu na cechy społeczno-ekonomiczne respondentów. Respondenci, którzy ocenili sytuację finansową swojej rodziny/gospodarstwa domowego jako przeciętną, to przede wszystkim (50\% i więcej odpowiedzi): osoby w wieku 40-49 lat, z dziećmi z niepełnosprawnością w wieku 13-15 lat, osoby mieszkające w miastach poniżej 20 tys. oraz 500 tys. i więcej mieszkańców, o dochodach netto z przedziału 3501-5000 tys. zł, mieszkający na terenie województwa mazowieckiego i pomorskiego. Profil respondentów, którzy ocenili sytuację finansową swojej rodziny/gospodarstwa domowego bardzo źle i bardzo dobrze, zamieszczono w tabeli 1. 
Tabela 1. Profil respondentów oceniających sytuację finansową swojej rodziny/gospodarstwa domowego bardzo źle i bardzo dobrze

\begin{tabular}{l|l|c|l}
\hline \multirow{2}{*}{ Wyszczególnienie } & \multicolumn{3}{c}{ Ocena sytuacji finansowej rodziny/gospodarstwa } \\
& Bardzo źle & $\%$ & Bardzo dobrze \\
\cline { 2 - 4 } & mężczyzna & 11 & mężczyzna \\
\hline Płeć & 50 lat i $>$ & 13 & 50 lat i $>$ \\
\hline Wiek & Podstawowe/zawodowe & 16 & wyższe \\
\hline Wykształcenie & $2-3$ osoby & 13 & 5 osób i $>$ \\
\hline Wielkość GD & $2-3$ & 15 & $1,2-3$ \\
\hline $\begin{array}{l}\text { Liczba dzieci z niepełnospraw- } \\
\text { nością do lat 18 }\end{array}$ & miasta 100-499 tys. & 14 & miasta 50-99 tys. \\
\hline Miejsce zamieszkania & do 1500 zł & 29 & powyżej 5000 zł \\
\hline Dochód netto GD & negatywna & 41 & pozytywna \\
\hline Ocena sytuacji finansowej & dolnośląskie & 19 & tódzkie \\
\hline Województwo & & & \\
\hline
\end{tabular}

Źródło: badanie własne, 2015.

Trudną sytuację rodzin z dziećmi z niepełnosprawnością dobrze oddają wypowiedzi w trakcie badania jakościowego (IDI):

Nie jest tak, że na wszystko wystarcza, trzeba ograniczać, żeby starczyło. [...] Najgorszy jest okres, kiedy dzieci idą do szkoły i trzeba wszystko kupić. $70 \%$ to są matki samotnie wychowujące dzieci, wegetujące, na garnuszku rodziców. Są dni, kiedy naprawdę nie ma co jeść. Bo są takie dni. Bo są miesiące, kiedy wydaje się więcej na te leki. My z jedzeniem, z bytowaniem to jedziemy po bandzie, [...], że dla dziecka jak najważniejsze, ale najważniejsze są opłaty i leki.

Zwraca uwagę pesymizm respondentów co do oceny sytuacji finansowej w najbliższym czasie, tj. w roku 2015. Blisko co trzeci respondent uważał, że sytuacja ta pogorszy się - 29\%, przy czym według $10 \%$ znacznie się pogorszy. Optymistów było znacznie mniej, bo 13\%, przy czym tylko zdaniem 3\% znacznie się poprawi. Ponad połowa (58\%) uważała, że sytuacja finansowa ich rodziny/ gospodarstwa domowego utrzyma się na podobnym poziomie.

O trudnej sytuacji badanych rodzin świadczą odpowiedzi o posiadanych oszczędnościach. Prawie co druga rodzina/gospodarstwo domowe nie posiadała oszczędności (49\%). Ci, co posiadali oszczędności, posiadali je głównie do wysokości trzech miesięcznych dochodów rodziny, co dziesiąte gospodarstwo miało oszczędności do wysokości sześciu miesięcznych dochodów rodziny, a 9\% powyżej sześciu miesięcznych dochodów rodziny.

W sytuacji ograniczonych dochodów rodziny/gospodarstwa domowe mogą skorzystać z pożyczek i kredytów. W ostatnim roku co trzecie badane gospodarstwo domowe zaciągnęło pożyczkę lub kredyt na cele konsumpcyjne. Prawie co szóste gospodarstwo miało jednak ciągle problem ze spłatą zasłużenia, a w co 
drugim taki problem pojawiał się od czasu do czasu. Tylko $29 \%$ badanych zadeklarował brak problemów ze spłatą zadłużenia (rysunek 3).

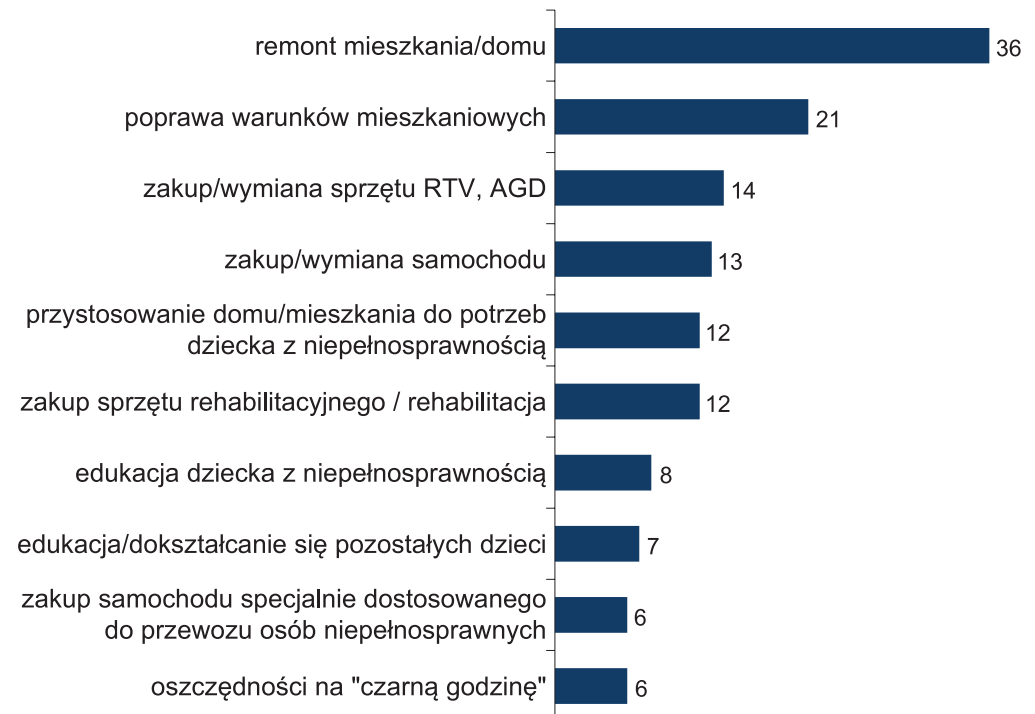

Rysunek 3. Cele konsumpcyjne zaciągniętych pożyczek/kredytów (\%)

Źródło: badanie własne, 2015.

Wśród zaciągających kredyt/pożyczkę był większy odsetek mężczyzn (37\%) niż kobiet (30\%), osób w wieku 40-49 lat (40\%) niż w pozostałych grupach wiekowych, z wykształceniem podstawowym (38\%) niż z średnim i wyższym. Ponadto były to osoby $z$ gospodarstw czteroosobowych $(38 \%)$, o dochodzie netto gospodarstwa domowego z przedziału 2501-3500 zł (42\%).

Wśród celów konsumpcyjnych zaciągniętych pożyczek/kredytów dominują cele związane z warunkami mieszkaniowymi, a następnie z wyposażeniem mieszkania i zakupem/wymianą samochodu. W dalszej kolejności plasują się wydatki związane ze sprzętem i rehabilitacją oraz edukacją dzieci. Poniżej 6\% wskazań znalazły się wydatki na wyjazd turystyczny dziecka (5\%) oraz na poprawę stanu zdrowia/ kondycji dziecka z niepełnosprawnością (4\%). Pozostałe wydatki dotyczyły przede wszystkim zaspokajania potrzeb dorosłych - wyjazd turystyczny, poprawa stanu zdrowia, oszczędności na przyszłą emeryturę, ale także poprawa stanu zdrowia/kondycji dziecka bez niepełnosprawności, zakup dostępu do internetu - po $2 \%$.

Typowa kolejność zaspokajania potrzeb (pomijając rodziny majętne): dziecko z niepełnosprawnością, rodzeństwo, dalej ewentualnie ojciec. Na potrzeby matki już nie starcza.

— Na potrzeby Wojtka wszystkie starcza [dziecko z niepełnosprawnością].

- A córki?

— No powiem tak, sobie mogę coś nie kupić, a jej muszę kupić. [...] Sobie mogę to kupić za miesiąc, za dwa. A jej kupię.

— Dla mnie dzieci i rodzina jest najważniejsza, ja tam na dalszy plan. 
— Patrzę wpierw dziecko, żeby miał w czym chodzić [...] teraz jest chory, lekarstwa 100 złotych. Dla mnie? Nic nie zostaje. Nie mam nawet co odłożyć. Nawet 500 złotych nie udaje mi się odłożyć.

\subsection{Najbardziej odczuwane braki}

Mimo że rodziny z dzieckiem/dziećmi z niepełnosprawnością podejmują różne działania, których celem jest poprawa sytuacji materialnej, a w efekcie zaspokojenie potrzeb, to jednak nadal występują obszary potrzeb niezaspokojonych. W badaniu zapytaliśmy o najbardziej odczuwane braki.

Największe braki, na jakie wskazywali rodzice/opiekunowie dzieci z niepełnosprawnością, dotyczyły warunków mieszkaniowych, wyjazdów na urlop dorosłych członków gospodarstwa domowego oraz odzieży i obuwia (rysunek 5).

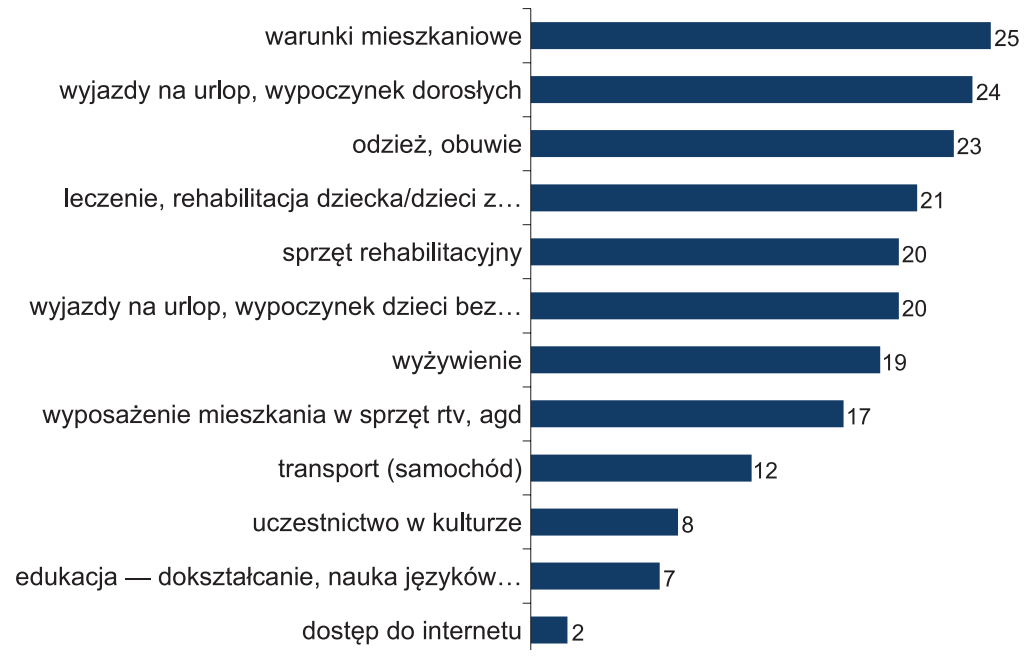

Rysunek 4. Najbardziej odczuwane braki w gospodarstwach domowych z dzieckiem/dziećmi $\mathrm{z}$ niepełnosprawnością (\%)

Źródło: badanie własne, 2015.

Odsetek deklarujących braki był zróżnicowany w zależności od cech społeczno-ekonomicznych respondenta. Uwzględniając przeciętną liczbę wskazań dotyczących braków na poziomie $20 \%$ i więcej, najwyższe odsetki braków wskazali respondenci o następujących cechach:

— warunki mieszkaniowe: kobiety, respondenci poniżej 30 lat, osoby z wykształceniem podstawowym/zawodowym, z gospodarstw domowych pięcioosobowych i więcej, z 2 dzieci z niepełnosprawnością, negatywnie oceniający sytuację finansową swojego gospodarstwa domowego, z miast o liczbie mieszkańców 50-59 tys., z województwa opolskiego;

- wyjazdy na urlop, wypoczynek dorosłych członków gospodarstwa domowego: kobiety, rodzice/opiekunowie młodzi do 30 lat, z wykształceniem średnim, z rodzin z dwojgiem dzieci, z miast o liczbie mieszkańców 20-49 tys., z gospo- 
darstw pozytywnie oceniających swoją sytuację finansową, z województwa warmińsko-mazurskiego;

— odzież i obuwie: kobiety, osoby z wykształceniem podstawowym/zawodowym, z gospodarstw domowych pięcioosobowych i więcej, z gospodarstw z trojgiem i więcej dziećmi, gospodarstw z miast o liczbie mieszkańców 20-49 tys., gospodarstwa negatywnie oceniające swoją sytuację finansową, co trzecie gospodarstwo z województwa małopolskiego;

— leczenie, rehabilitacja dziecka/dzieci z niepełnosprawnością: kobiety, osoby w wieku 50 lat i więcej, z wykształceniem podstawowym, niepracujący, z dwutrzyosobowych, z trojgiem dzieci i więcej, z miast o liczbie mieszkańców 500 tys. i więcej, oceniający sytuację finansową swojego gospodarstwa jako przeciętną, z województwa zachodniopomorskiego;

— sprzęt rehabilitacyjny: osoby w wieku 50 lat i więcej, z wykształceniem wyższym, z gospodarstw z pięciorgiem i więcej osobami, z gospodarstw z trojgiem i więcej dzieci, z miast o 100-499 tys. mieszkańców, oceniający sytuacje finansową swojej rodziny jako przeciętną, z województwa podlaskiego;

- wyjazdy na urlop, wypoczynek dzieci bez niepełnosprawności: osoby w wieku 40-49 lat, z wykształceniem średnim, mieszkańcy wsi, oceniający sytuacje finansową swojej rodziny jako przeciętną osoby z województwa świętokrzyskiego.

Uwzględniając tylko najwyższe odsetki wskazań dotyczące odczuwanych braków według liczby dzieci do lat 18 z niepełnosprawnością oraz wiek tych dzieci, to dominującymi brakami, tak jak w ujęciu ogółem, były warunki mieszkaniowe oraz wyjazdy wypoczynkowe osób dorosłych (tabela 2).

Tabela 2. Odczuwane największe braki według liczby dzieci do lat $18 \mathrm{z}$ niepełnosprawnością oraz wiek tych dzieci

\begin{tabular}{l|l|c}
$\begin{array}{c}\text { Liczba i wiek dziecka/dzieci } \\
\text { z niepełnosprawnością }\end{array}$ & \multicolumn{1}{c}{ Odczuwane największe braki } & $\%$ \\
\hline \multicolumn{2}{c}{ Liczba dzieci do 18 lat z niepełnosprawnością } & po 25 \\
\hline 1 dziecko & $\begin{array}{l}\text { warunki mieszkaniowe, } \\
\text { wyjazdy na urlop, wypoczynek dorosłych }\end{array}$ & 35 \\
\hline 2-3 dzieci & warunki mieszkaniowe & 26 \\
\hline \multicolumn{2}{c|}{ Dzieci niepełnosprawne } & 30 \\
\hline dzieci niepełnosprawne 0-3 & sprzęt rehabilitacyjny & 27 \\
\hline dzieci niepełnosprawne 4-6 & wyjazdy na urlop, wypoczynek dorosłych & po 27 \\
\hline dzieci niepełnosprawne 7-12 & warunki mieszkaniowe & 24 \\
\hline dzieci niepełnosprawne 13-15 & odzież, obuwie warunki mieszkaniowe \\
\hline dzieci niepełnosprawne 16-18 & wyjazdy na urlop, wypoczynek dorosłych & \\
\hline
\end{tabular}

Źródło: badanie własne, 2015. 
Interesująco w kontekście występujących braków przedstawiają się wydatki w sytuacji znaczącego wzrostu dochodów gospodarstwa domowego. W pierwszej kolejności dochód ten zostałby przeznaczony na wydatki związane z mieszkaniem - poprawę warunków mieszkaniowych, remont mieszkania/domu, przystosowanie domu/mieszkania do potrzeb dziecka $\mathrm{z}$ niepełnosprawnością. W dalszej kolejności, w hierarchii ważności, byłyby to wydatki związane z potrzebami dziecka z niepełnosprawnością (do takich można zaliczyć też zakup/wymianę samochodu), potrzebami dzieci bez niepełnosprawności i dopiero w następnej kolejności byłyby to wydatki na zaspokojenie potrzeb dorosłych członków rodziny/gospodarstwa domowego. Wyjazd na urlop, turystyczny dorosłych członków gospodarstwa, który obok warunków mieszkaniowych był najbardziej odczuwanym brakiem, znalazł się dopiero na jednej z końcowych pozycji, jeśli chodzi o wydatki w przypadku znacznego wzrostu dochodów (rysunek 5).

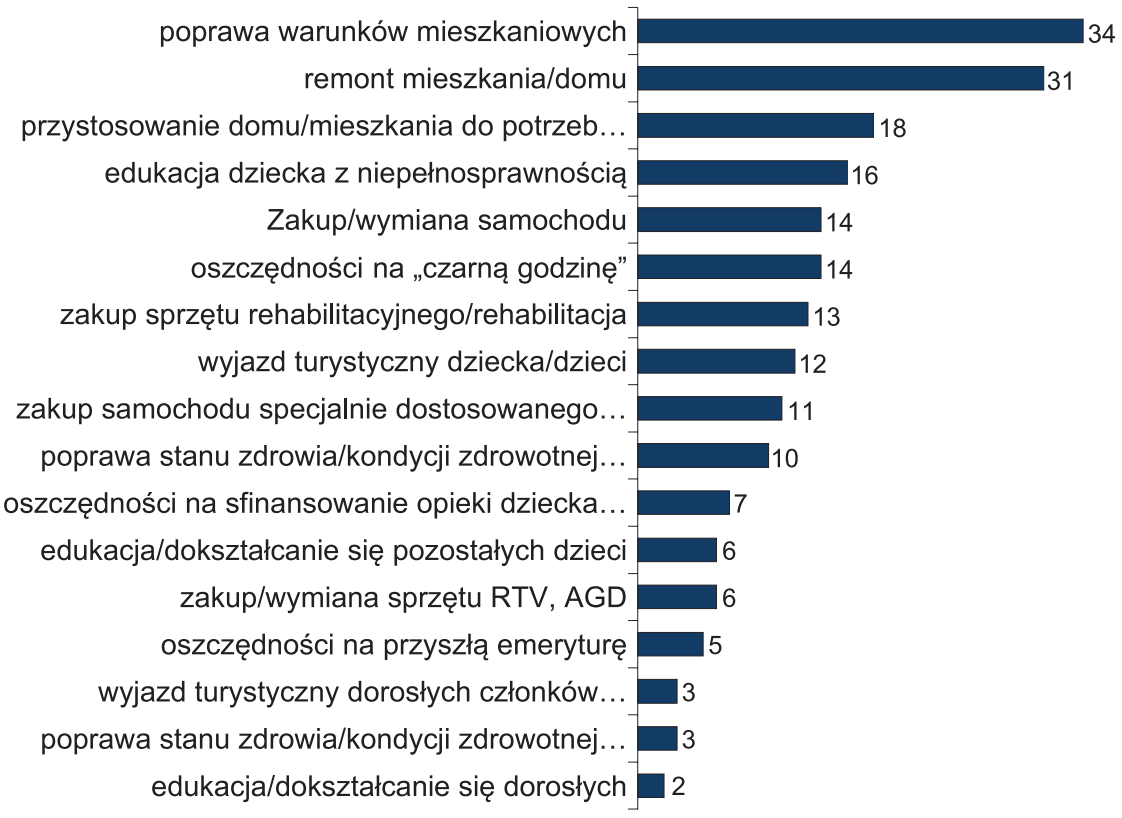

Rysunek 5. Przeznaczenie dodatkowych dochodów

Źródło: badanie własne, 2015.

Cele zaciąganych pożyczek lub kredytów, najbardziej odczuwane braki oraz kierunki wydatkowania dochodów przy założeniu ich znaczącego wzrostu, wskazują przede wszystkim na występowanie problemów mieszkaniowych wśród gospodarstw z dzieckiem/dziećmi z niepełnosprawnością. Mieszkanie/dom wraz z jego wyposażeniem jest rzeczowym wymiarem procesu konsumpcji, tworzy swoistą infrastrukturę konsumpcyjną. Ale co najważniejsze, zaspokaja podstawową potrzebę schronienia oraz umożliwia zaspokajanie innych potrzeb zarówno podstawowych, 
jak i wyższego rzędu. Posiadanie mieszkania jest warunkiem prawidłowego funkcjonowania każdego gospodarstwa domowego. Nie dziwi zatem, że rodziny/gospodarstwa domowe z dziećmi z niepełnosprawnością chcą przede wszystkim poprawić swoje warunki mieszkaniowe, zwłaszcza że co czwarta rodzina zadeklarowała mieszkanie z rodzicami, a prawie co szósta wynajmuje mieszkanie lub dom.

$\mathrm{W}$ badaniu jakościowym respondenci niejednokrotnie zwracali uwagę na niezaspokojone potrzeby rodziców/opiekunów, żeby mogli mieć czas wyłącznie dla siebie i to właśnie na taki cel przeznaczyliby pieniądze oraz na pomoce dydaktyczne.

— Ja marzę tylko o jednym dniu, gdzie mogłabym pójść do kina, do jakiegoś spa. Gdziekolwiek. Zająć się sama sobą. [...] Ale żebym była spokojna, że jemu nic się nie stanie.

- Bo wszystkie nasze wolne środki idą na Kubę. Potrzebowałabym tego [czasu wolnego dla siebie — M.J.K.], żebym mogła bardziej o siebie zadbać. Żebym mogła pójść do kosmetyczki, na fitness... o takie rzeczy i chodzi, żebym mogła się dopieścić.

- Nasze wakacje to mniej więcej raz na dwa-trzy lata jedziemy do rodziny do Gdańska na weekend. To wszystko. Nasze wakacje. Po prostu nie mamy ani funduszy na to, ani czasu, ani gdzie się zatrzymać. Za granicą w życiu nie byłam i podejrzewam, że nigdy nie będę.

\subsection{Radzenie sobie $z$ trudnościami}

Rodziny z dziećmi z niepełnosprawnością korzystają niejednokrotnie ze wsparcia ze strony różnych osób czy instytucji i organizacji (rysunek 6).

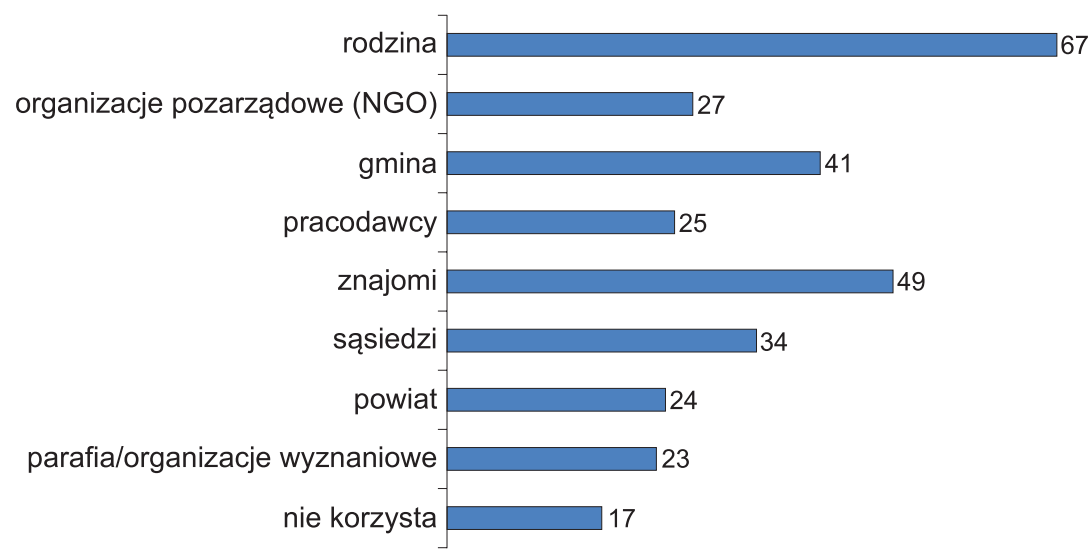

Rysunek 6. Korzystanie z pomocy/wsparcia osób i instytucji (\%)

Źródło: badanie własne, 2015.

Przede wszystkim mogą liczyć na rodzinę i znajomych, a w następnej kolejności na gminę i sąsiadów. Co szósta badana rodzina nie korzystała ze wsparcia.

Formy pomocy/wsparcia są różne, zarówno finansowe od rodziny, ale i znajomych, i rzeczowe, jak i emocjonalne. Zaspokojenie potrzeb rodziny, w tym zwłaszcza dziecka/dzieci z niepełnosprawnością, przy niewystarczającym wsparciu instytucji zewnętrznych wymaga aktywnej postawy rodziców, szczególnie matki/opiekunki prawnej: „Motywacją dla mnie do działania jest to, że ja dostanę Ekonomia - Wroclaw Economic Review 23/1 (2017)

(C) for this edition by CNS 
jakiś dochód. To nie jest tak, że to są pieniądze przeznaczone dla mnie, czasem ktoś mówi zrób to i to, a ja wpłacę na konto twojego dziecka, to to jest również dla mnie motywacja".

Przejawem tej aktywności było wykorzystanie wszystkich znanych im dostępnych środków, jak np. skuteczne staranie się o dofinansowanie, korzystanie $\mathrm{z}$ funduszy socjalnych w zakładach pracy, orientacja w prawie i ofercie pomocowej, łącznie (gdy zajdzie taka potrzeba) odwołania się do instytucji centralnej, gdy zawiodą instytucje samorządowe. Ta swoistego rodzaju przedsiębiorczość dotyczyła także poszukiwania sponsorów, organizowanie zbiórek, zakładania subkont dla dzieci i aktywnego poszukiwania donatorów swego 1\% — „Udało nam się zbiórkę w mieście zrobić, sponsorów pozyskać [...]. W życiu bym nie pomyślała, że uda nam się zebrać tyle pieniędzy" (akcja miasta i MOPS).

Badani rodzice/opiekunowie podejmowali też różne prace sezonowe, dorywcze, sprzedawali zbędne rzeczy (np. ubranka, sprzęt rehabilitacyjny) czy własne wyroby kulinarne, rękodzieła itp., ale też ojciec/opiekun przejawiał większą aktywność zawodową. Niewielkim zainteresowaniem cieszyła się konsumpcja kolaboratywna (Janoś-Kresło, 2015, s. 27-39).

Nie wszystkie rodziny/gospodarstwa domowe korzystały z pomocy, także $\mathrm{z}$ tych przysługujących im refundacji, nie miały też subkonta $\mathrm{w}$ fundacjach. Powody były różne - zarówno uznanie, że jest więcej dzieci, które potrzebują pomocy (rodzice sami rehabilitują dziecko), jak i uciążliwość procedur związana ze zwrotem kosztów przejazdów: „Mnie nie chce się w to bawić [dokumentacja przejazdów - M.J.K.]. Gdyby to było opłacalne, ale oni zwracają jakiś tam procent, to jest na tyle pracochłonne i zawiłe, że żeby nie mieć problemów z urzędem skarbowym najlepiej dać to księgowemu".

\section{Wnioski}

Konsumpcja to nie tylko siła napędowa gospodarki. Wokół konsumpcji toczy się życie codzienne, rodziny/gospodarstwa domowe podejmują różne działania, których celem jest zaspokojenie potrzeb poszczególnych potrzeb członków, jak też rodziny/gospodarstwa jako całości.

Badania wśród rodzin/gospodarstw domowych z dzieckiem/dziećmi z niepełnosprawnością wykazały, że dochód rodzin/gospodarstw domowych z dzieckiem/ dziećmi z niepełnosprawnością nie zawsze wystarczał na zaspokojenie potrzeb w sposób je satysfakcjonujący. Gospodarstwa te odczuwają braki, a za najbardziej odczuwane uznano przede wszystkim niedostakti w zakresie warunków mieszkaniowych, wypoczynku osób dorosłych oraz odzieży i obuwia. Jednak znaczący wzrost dochodów wydatkowany byłby na szeroko rozumianą poprawę warunków mieszkaniowych oraz inne potrzeby dotyczące dzieci z niepełnosprawnością. Wydatki na zaspokojenie potrzeby wypoczynku dorosłych członków gospodarstwa domowego plasują się na dalszej pozycji. 
Mimo borykania się z wieloma trudnościami dnia codziennego, występujących niedoborów konsumpcji, na pytanie, czy rodzina jest szczęśliwa mimo posiadania dziecka/dzieci z niepełnosprawnością, ponad połowa respondentów (57\%) odpowiedziała tak, w tym 25\% ,zdecydowanie tak”, a 32\% ,raczej tak”.

\section{Bibliografia}

Budżety gospodarstw domowych z roku 2013 i 2014, Główny Urząd Statystyczny, Warszawa.

Bylok F. (2013), Konsumpcja, konsument i społeczeństwo konsumpcyjne we współczesnym świecie, Katowice.

Dąbrowska A., Janoś-Kresło M., Słaby T., Witek J. (2013), Niedobory konsumpcji w polskich gospodarstwach domowych, Warszawa.

Janoś-Kresło M. (2015), Postawy wobec konsumpcji kolaboratywnej rodzin z dziećmi z niepetnosprawnościa, „Konsumpcja i Rozwój” nr 4, s. 27-39, ibrkk.pl/f/?konsumpcja_i_rozwoj_13. pdf.

Janoś-Kresło M., Komorowska O., Skalska T. Słaby T. (2016), Zachowania przedsiębiorcze i konsumpcyjne w rodzinach opiekujących się dziećmi i młodzieża z niepetnosprawnościa, Warszawa.

Sytuacja gospodarstw domowych w 2015 r. w świetle wyników badania budżetów gospodarstw domowych (25 maja 2016), notatka informacyjna, Główny Urząd Statystyczny, Warszawa.

Wartości i normy (sierpień 2013), Komunikat CBOS BS/111/2013, Warszawa. 